\title{
ІНФЛЯЦІЯ: СУТНІСТЬ, ВИДИ ТА ШЛЯХИ ПОДОЛАННЯ
}

\author{
Крістіна Олегівна Яцко \\ Україна, ДВНЗ "Чернівецький політехнічний коледж", викладач
}

DOI: https://doi.org/10.31435/rsglobal_ijite/01062018/5660

\section{ARTICLE INFO}

Received 20 April 2018

Accepted 23 May 2018

Published 01 June 2018

\section{KEYWORDS}

inflation, anti-inflationary measures, causes of inflation, creeping inflation, galloping inflation, hyperinflation

\begin{abstract}
The strengthening of inflationary trends in the economy and the significant consequences and problems of further development of the state identified the subject of this study. The purpose of the work is to find out the causes of inflationary processes and ways to overcome them.
\end{abstract}

(C) 2018 The Author.

Інфляція - це процес зростання загального рівня цін в країні внаслідок порушення закону грошового обігу. Інфляція виникає тоді, коли в обігу знаходиться надлишкова кількість грошей. Таке становище веде до їх знецінення, а ціни набувають тенденції до зростання.

$€$ чотири основні причини виникнення інфляції:

- диспропорційність, або незбалансованість державних витрат i доходів, що проявляється в дефіциті державного бюджету. Якщо цей дефіцит фінансується за рахунок активного використання «друкарського верстата», це призводить до збільшення маси грошей в обігу, а відповідно і до інфляції.

- інфляційне зростання цін може відбуватись, якщо фінансування інвестицій проводиться аналогічними методами. Особливо інфляційне небезпечними $є$ інвестиції, пов'язані з мілітаризацією економіки.

- 3 зростанням «відкритості» економіки, все більшим втягуванням пї в мікрогосподарські зв'язки збільшують небезпечність «імпортованої» інфляції.

- інфляція набуває самопідтримуючий характер в результаті інфляційних очікувань.

У міжнародній практиці виокремлюють три різновиди інфляції: повзучу, галопуючу, гіперінфляцію. Повзуча інфляція настає тоді, коли темпи зростання цін не перевищують $10 \%$ на рік. Вона характеризується надмірною емісією та прискореним накопиченням грошової маси в каналах обігу без помітного підвищення чи за незначного зростання цін. [1, с. 851]

Галопуюча інфляція настає тоді, коли темпи зростання цін досягають 10-100\% на рік. Вона спричиняє випереджальні темпи зростання споживчого попиту порівняно 3 товарною пропозицією, що призводить до зростання цін. За цих умов формується інфляційний мультиплікатор, який прискорює деструктивні процеси в економіці.

Особливо виразно деформація економічних та соціальних процесів проявляється за гіперінфляції. Інфляція переходить у гіперстадію, коли темпи приросту цін зростають до 50 \% за місяць. [2, с. 12]

Світова практика знає цілий арсенал боротьби з інфляцією. Цей арсенал 3 певною умовністю можна поділити на дві частини. Відома антиінфляційна стратегія, що об'єднує цілі і методи тривалого характеру та антиінфляційна тактика, від якої можна чекати результатів у межах порівняно невеликого відрізку часу.

Одним із найважливіших завдань антиінфляційної стратегії є гасіння інфляційних очікувань. Для подолання психології суб'єктів економічної системи, позбавлення їх страху перед знеціненням заощаджень, відвернення нагнітання поточного попиту, який зумовлений 
безперервним подорожчанням товарів і послуг, необхідно зупинити інфляцію. Світовий досвід показує, що інфляційні очікування якнайшвидше долалися там, де виконувалися принаймні дві умови. Перша із них - всебічне зміцнення механізмів ринкової системи. Тільки вони здатні викликати природне, що супроводжується збільшенням кількості і підвищенням якості товарів, зниження цін або хоча б уповільнення їхнього зростання. Другою умовою $є$ існування уряду, який непохитно дотримується курсу на поступове викорінення не керуючої інфляції $\mathrm{i}$ користується довір'ям більшості населення. Заслужити це довір'я, щоправда, можна лише тоді, коли уряд ставить перед собою цілком визначені, практично здійснимі і такі, що можна легко перевірити, антиінфляційні завдання, заздалегідь інформує про це населення i неухильно домагається розв'язання цих завдань.

Другим невід'ємним компонентом антиінфляційної стратегії $\epsilon$ тривала грошова політика. Ї̈ відмінна особливість - введення жорстких лімітів на щорічні прирости грошової маси. Цей показник визначається довгостроковим темпом зростання реального виробництва i таким рівнем інфляції, який уряд вважає прийнятним і зобов'язується контролювати. Для того щоб грошова політика була справді антиінфляційною, вказаного ліміту треба дотримуватися протягом тривалого часу i, найважливіше, незалежно від стану бюджету, інтенсивності інвестиційного процесу, рівня безробіття тощо. [3].

Проведення центральними банками стабілізаційної й антиінфляційної політики передусім здійснюється за допомогою таких економічних важелів, як облікова ставка, норма обов'язкових резервів і операції на відкритому ринку. Перші два важелі (регулятори) запускають механізми непрямої дії, що з'єднують центральний банк $з$ іншими ланками банківської системи. Підвищуючи облікову ставку і норми обов'язкових резервів, центральний банк задає цій системі не інфляційну лінію поведінки. Використовуючи третій регулятор, центральний банк уже безпосередньо впливає на стан грошового обігу. Саме він володіє найбільшою силою впливу на грошову масу. Важливим заходом антиінфляційної політики $\epsilon$ скорочення бюджетного дефіциту з перспективою його повної ліквідації до його здійснення можна йти двома шляхами - через збільшення доходів і зменшення видатків держави. [4].

Ефективна антиінфляційна стратегія має бути побудована так, щоб звести до мінімуму вплив на національну економіку зовнішніх інфляційних імпульсів, що пов'язані 3 переміщеннями через кордони спекулятивних капіталів. Особливе місце в антиінфляційній діяльності займає державне регулювання валютного курсу. Первісне співвідношення валют різних країн залежить від співвідношення цін на товари, які надходять в обмін. В умовах товарного дефіциту і зменшення обсягів виробництва курс національної валюти кон'юктурно знижується через підвищений попит на імпорт. Держава своїми часто необгрунтованими діями може сприяти "роздуванню" попиту на імпорт, на іноземну валюту. Внутрішня конвертованість національної валюти за значного дефіциту товарів розвиває попит на іноземну валюту. [4].

При виникненні нестерпної інфляційної ситуації, необхідно мобілізувати тактичний механізм, швидкодіючий потенціал антиінфляційного регулювання. Таким першим шляхом антиінфляційної тактики необхідно виділити державну підтримку підвищення ступеня товарності народного господарства. Зокрема, пільгове оподаткування підприємств, що організують вільний продаж продуктів виробництва i послуг. Подібний різновид диверсифікації не потребує значних витрат, у тому числі на заробітну плату, а тому сприяє чистому приросту пропозиції і хоча б тимчасовому припиненню інфляційних процесів.

Великий антиінфляційний заряд несе в собі розумно організована приватизація державної власності. Вона характеризується збільшенням державних доходів і послабленням напруженості у видатковій частині бюджету. Дієвими засобами короткострокової антиінфляційної політики можуть стати масований імпорт споживчих товарів і часткова реалізація державних стратегічних запасів, а ще й такий антиінфляційний резерв, як продаж населенню частини нагромаджених підприємствами матеріальних ресурсів виробничого призначення.

\section{ЛІТЕРАТУРА}

1. Базилевич В. Д. Макроекономіка: Підручник/ В. Д. Базилевич, К. С. Базилевич, Л. О. Баластрик. - К.: Знання, 2004. - 851 с.

2. Бубенко С. Інфляція та експортна політика в Україні / С. Бубенко // Банківська справа. - 2000. - № 2. - С. 12.

3. Полотенко Д. В. Про гроші, інфляцію та фінанси у трансформаційній економіці» // Фінанси України. - 2008. - № 2.

4. Петрик О., Половньов Ю. Прогнозування інфляції // Вісник НБУ. —2004. — № 12. 